\title{
ANALISIS FAKTOR FAKTOR DETERMINAN DAN PERILAKU HERDING DI PASAR SAHAM
}

\author{
Adik Duwi Rahayu', Aditya Putra ${ }^{2}$, Chiata Oktaverina ${ }^{3}$, Regina Aulia Ningtyas 4 \\ ${ }^{1,2,3,4}$ Program Studi Akuntansi, Fakultas Pendidikan Ekonomi dan Bisnis, \\ Universitas Pendidikan Indonesia, Bandung, Indonesia \\ adidwi12@student.upi.edu ${ }^{1}$, adityaputra@student.upi.edu ${ }^{2}$, chiataoktaverina@ student.ui.edu ${ }^{3}$, \\ Reginaaulian@student.upi.edu4
}

\begin{abstract}
This article aims to prove the existence of herding behavior in a number of stock markets in various parts of the world and find out the factors that cause herding behavior. The method used in this article is a research library by taking data from 80 international journals and 4 local journals. The results of our analysis conclude that herding behavior occurs in almost all stock markets in the world. Factors that cause herding behavior include negative news sentiments towards stocks, incentives and career concerns owned by analysts, market risk and firm level uncertainty, market uncertainty, extreme market conditions, periods of high information flow, risk of volatility, analysis of more types of stocks small, economic I financial crisis, declining market conditions, rising interest rates, currency depreciation, poor information environment, and low quality disclosures. The limitation of this article is that the amount of data taken from the results of research in several stock markets is uneven, such as the lack of data retrieval from the stock market on the American continent.
\end{abstract}

Keywords: analyst securities; stock market; herding behavior.

\begin{abstract}
Abstrak
Artikel ini bertujuan untuk membuktikan keberadaan perilaku herding di sejumlah pasar saham di berbagai belahan dunia dan mengetahui faktor-faktor penyebab perilaku herding. Metode yang digunakan dalam artikel ini adalah perpustakaan penelitian dengan mengambil data dari 80 jurnal internasional dan 4 jurnal lokal. Hasil analisis kami menyimpulkan bahwa perilaku herding terjadi di hampir semua pasar saham di dunia. Faktor-faktor yang menyebabkan perilaku herding meliputi sentimen berita negatif terhadap saham, insentif dan kekhawatiran karier yang dimiliki oleh analis, risiko pasar dan ketidakpastian tingkat perusahaan, ketidakpastian pasar, kondisi pasar ekstrem, periode arus informasi tinggi, risiko volatilitas, analisis jenis saham yang lebih kecil, terjadinya krisis ekonomi/keuangan, kondisi pasar yang menurun, kenaikan suku bunga, depresiasi mata uang, lingkungan informasi yang buruk, dan pengungkapan berkualitas rendah. Keterbatasan artikel ini adalah jumlah data yang diambil dari hasil penelitian di beberapa pasar saham tidak merata, seperti kurangnya pengambilan data dari pasar saham di Amerika.
\end{abstract}

Kata Kunci: analis sekuritas; pasar saham; perilaku herding.

Corresponding author. Email : adidwi12@student.upi.edu

History of article : Received: Juli 2019, Revised : September 2019, Published: November 2019 


\section{PENDAHULUAN}

Bursa efek merupakan salah satu tempat bagi investor untuk memperoleh keuntugan melalui perdagangan saham. Saham lebih banyak dipilih investor dibandingkan instrumen keuangan lainnya karena hasil yang akan diperoleh lebih besar meskipun diikuti dengan risiko yang tinggi. Dalam perdagangan saham yang dilakukan, investor perlu memiliki stategi tersendiri dengan analisis yang rasional untuk mencegah risiko lebih tinggi lagi. Namun, ada beberapa kasus dimana investor menantang dirinya untuk melawan risiko tinggi demi memperoleh keuntungan yang lebih besar. Keserakahan merangsang investor untuk melakukan investasi yang semakin berisiko, maka investor cenderung saling mengikuti secara membabi buta dan mengabaikan analisis rasional (Ullah \& Ather, 2014). Kecenderungan yang dimaksud adalah herding behavior (perilaku berkelompok) yang biasanya didefinisikan sebagai perilaku investor untuk meniru tindakan orang lain yang diamati atau pergerakan pasar alih-alih mengikuti keyakinan dan informasinya sendiri (Elena, 2013).

Bikhchandani \& Sharma (2000) mengklasifikasikan perilaku berkelompok menjadi spurious herding dan intentional herding (Kim \& Park, 2017). Spuriour herding yang dimaksud apabila investor bereaksi terhadap informasi yang terkenal di kalangan publik dengan membuat keputusan investasi yang sama dengan informasi tersebut. Sedangkan, jika investor memiliki niat untuk mengikuti perilaku investor lain, maka hal tersebut merupakan intentional herding (Kim \& Park, 2017). Meskipun akan sulit untuk membedakan spurious herding dan intentional herding, namun hal ini menjadi tantangan tersendiri untuk menemukan perbedaan yang tampak sangat penting untuk mencegah analisis yang salah. Intentional herding yang parah akan menyeabkan risiko sistematis, fenomena gelembung, dan volatilitas asimetris di pasar keuangan (Bikhchandani, Hirshleifer, \& Welch, 1992; Kodres \& Pritsker, 2002; Park, 2011).

Dari prespektif perilaku, dilema perdagangan pasar saham merupakan refleksi kumulatf dari perilaku investor (Foucault, Sraer, \& Thesmar, 2011). Ditemukan beberapa bias psikologi yang berkontribusi dalam perilaku herding. Investor menunjukan penyimpangan perilaku (bias) yang berpotensi memengaruhi efisiensi pasar (Barber \& Odean, 2000; Kumar \& Goyal, 2015). Disisi rasional, investor dapat memilih untuk meniru jika mereka menganggap perilaku berkelompok dapat menambah informasi dan menguntungkan mereka (Andrea Devenow \& Ivo Welch, 1996; Kallinterakis, Munir, \& Radovic-Markovic, 2010). Seorang investor, misalnya, mendapatkan informasi yang memadai untuk mengambil keputusan atau investor lebih meyakini bahwa orang lain memiliki informasi yang lebih baik, dapat memutuskan untuk meniru tindakan orang lain jika menganggapnya informatif.

Dalam studi ini akan memfokuskan faktor- faktor yang menjadi penyebab perilaku berkelompok (herding behavior) dari seorang investor pada pasar saham. Beberapa literature telah dikumpulkan untuk dapat dikomparasikan sehingga dapat mengetahui faktor-faktor apa saja yang menjadi penyebab perilaku berkelopok (herding behavior) di pasar saham.

\section{KAJIAN PUSTAKA \\ Teori Perilaku Terencana (Theory of Planned Behavior)}

Teori perilaku terencana atau Theory of Planned behavior (TPB) merupakan pengembangan lebih lanjut dari Theory of Reasoned Action (TRA). Theory of reasoned action (TRA) didsasarkan kepada asumsi bahwa manusia berperilaku dengan cara yang sadar, dengan memper-timbangkan informasi yang tersedia dan juga mempertimbangkan implikasi-implikasi dari tindakan yang 
dilakukan. Menurut TRA, niat
merupakan faktor yang memengaruhi terjadinya suatu tindakan (Ajzen, 1991). Niat dipengaruhi oleh dua faktor dasar, yaitu faktor pribadi berupa sikap dan faktor pengaruh sosial yaitu norma subyektif (Ajzen, 1991).

Menurut Ajzen dalam jurnal Fatameh Sohari dan Mostafa Ahmadvand (Soorani \& Ahmadvand, 2019) dijelaskan bahwa Kerangka teori perilaku terencana telah dirancang untuk memprediksi dan menjelaskan perilaku manusia dalam konteks tertentu. Teori ini adalah salah satu yang paling populer saat ini, dan salah satu model sosial-psikologis untuk memahami dan memprediksi perilaku manusia. Teori perilaku terencana adalah berdasarkan pada asumsi bahwa manusia biasanya berperilaku secara masuk akal cara. Mereka memperhatikan informasi yang tersedia dan secara implisit atau eksplisit menganggap implikasi tindakan mereka. Dalam kerangka teori perilaku yang direncanakan, diasumsikan bahwa motivasi dan niat akan sangat mempengaruhi seseorang dalam berprilaku atau mengambil keputusan.

Ajzen (Ajzen, 1991) menambahkan konstruk yang belum ada dalam TRA, yaitu persepsi kontrol keprilakuan (perceived behavioral control). Konstruk ini ditambahkan dalam upaya memahami keterbatasan yang dimiliki individu dalam rangka melakukan perilaku tertentu. Teori perilaku terencana atau theory of planned behavior (TPB) adala teori yang mencakup tiga hal, yang pertama adalah keyakinan tentang kemungkinan evaluasi dan hasil dari perilaku tersebut. Kedua yaitu keyakinan tentang norma perilaku yang diharapkan dan motivasi untuk sampai atau memenuhi harapan tersebut. Ketiga adalah keyakinan tentang adanya 16 faktor yang bisa mendukung atau menghambat perilaku dan kesadaran akan kekuatan faktor tersebut (control beliefs). Control beliefs memunculkan kontrol terhadap perilaku tersebut (Ajzen, 1991). Teori perilaku terencana memuat keyakinan- keyakinan berpengaruh pada sikap terhadap perilaku tertentu pada norma-norma subjektif, dan pada kontrol perilaku yang dihayati. Semua komponen tersebut berinteraksi dan menjadi faktor utama bagi intensi yang pada saatnya akan menunjukan apakah perilaku yang direncanakan akan dilakukan atau tidak.

\section{Perilaku Mental Discounting}

Mental discounting merupakan proses kognitif untuk melakukan estimasi terhadap discount rate atau return (Wahlund \& Gunnarsson, 1996). Mental discounting sebagai bentuk mental attitude didukung oleh tiga faktor, yaitu: pertama, determination: adanya motivasi, niat, dan tujuan yang kuat. Kedua, self dicipline: mengetahui apa dan kapan harus melakukan sesuatu. Ketiga, fighting: kerja keras, kerja cerdas, dan manajemen waktu. Proses mental discounting memerlukan kapabilitas tinggi yang berhubungan dengan kemampuan individu dalam aspek kognitif, afeksi, dan konasi seperti; pemrosesan informasi keuangan dan non keuangan, penerapan pengetahuan investasi dari aspek fundamental dan teknikal, perubahan preferensi investasi, persepsi risk dan return, serta pembelajaran proses investasi. Berkaitan dengan studi ini, mental discounting didefinisikan sebagai kecenderungan niat untuk memilih saham kandidat yang ditentukan secara langsung oleh keyakinan yang dimiliki analis efek terhadap estimasi return saham. Mental discounting didefinisikan sebagai kecenderungan niat untuk memilih saham kandidat yang ditentukan secara langsung oleh keyakinan yang dimiliki analis efek terhadap estimasi return saham.

\section{Herding Behavior}

Herding behavior merupakan perilaku investor yang cenderung mengikuti investor lain dalam berinvestasi tanpa melakukan analisis fundamental terlebih dahulu sehingga pasar yang terbentuk menjadi tidak efisien (Fityani \& Arfinto, 2015). Herding dijelaskan 
sebagai investor atau sekumpulan investor cenderung berperilaku mengikuti investor lain (Saputra \& Sitinjak, 2018). Saastamoinen dalam (Ramadhan \& Mahfud, 2016) menjelaskan bahwa herding merupakan perilaku investor menjual atau membeli sekuritas/saham tanpa menghiraukan alasan yang menjadi dasar untuk melakukan investasi.

\section{METODE PENELITIAN}

Dalam penulisan artikel ini, kami menggunakan jenis penelitian kepustakaan (library research), yaitu serangkaian kegiatan yang berkenaan dengan metode pengumpulan data pustaka. Library reseacrch ini digunakan untuk mencari informasi yang relevan, serta memahami secara mendalam untuk mengetahui permasalahan yang telah diteliti oleh penulis sebelumnya. Metode yang digunakan dalam artikel ini adalah metode analisis deskriptif.

Teknik pengumpulan data merupakan langkah yang paling utama dalam penulisan. Dalam artikel ini, kami menggunakan data sekunder yang berasal dari jurnal internasional yang didapat dari beberapa website penyedia jurnal seperti Emerald, Directory of Open Acces Journal, Scopus, Thomson Reuters, Elsevier, Springer dan Wiley online library, Science Drirect, Researchgate dan google scholar mengenai Herding Behavior dalam pasar saham. Kajian literatur lengkap dilakukan dengan mengindentifikasi jurnal internasional mengenai perilaku Herding Behavior dalam pasar saham yang telah diterbitkan dari tahun 2009 hingga 2019. Secara total 600 jurnal internasional yang didapat, dan dipilih 80 jurnal internasional dan 4 jurnal lokal kemudian dipilih 50 jurnal utama yang dianalisis dan dijadikan sumber utama dari isi artikel ini.

\section{HASIL DAN PEMBAHASAN}

Mental discounting didefinisikan sebagai kecenderungan niat untuk memilih saham kandidat yang ditentukan secara langsung oleh keyakinan yang dimiliki analis efek terhadap estimasi return saham. Isu ini mengkaji niat analis efek dalam pemilihan saham sebagai hasil estimasi prospek saham untuk rekomendasi kepada investor (mental discounting). Mental discounting dipengaruhi informasi keuangan dan non-keuangan, revisi keyakinan, norma subyektif, dan persepsi risiko serta berimplikasi pada maksimalisasi utilitas (Adhikara, 2011). Berdasarkan penjelasan tersebut dapat disimpulkan bahwa perilaku mental discounting dapat dikaitkan dengan perilaku analis efek (securities analyst behavior) dalam proses pemilihan saham. Proses mental discounting memerlukan kapabilitas tinggi yang berhubungan dengan kemampuan individu dalam aspek kognitif, afeksi, dan konasi seperti; pemrosesan informasi keuangan dan non keuangan, penerapan pengetahuan investasi dari aspek fundamental dan teknikal, perubahan preferensi investasi, persepsi risk dan return, serta pembelajaran proses investasi (Adhikara, 2011).

Hasil analisis dari analis efek dalam memilih saham sangat penting bagi investor karena bermanfaat untuk keberhasilan investasi yang dilakukan oleh investor. Perkiraan harga oleh analis efek untuk IPO adalah dasar penting bagi investor untuk menilai nilai IPO. keakuratan dan dispersi perkiraan harga oleh analis sekuritas memiliki dampak signifikan pada premi IPO, yang membuktikan efektivitas perilaku perkiraan harga oleh analis sekuritas, dan analis dapat membantu investor menilai IPO dengan lebih baik (Jiani \& Liu, 2014). Hasil penelitian (Mihaylov, Cheong, \& Zurbruegg, 2015) menunjukkan bahwa ada beberapa bukti yang menunjukkan bahwa perkiraan pendapatan agregat oleh analis sekuritas berisi informasi yang berharga untuk prediksi harga emas di masa depan. Analis efek (broker) memiliki peran penting dalam pengembalian pasar misalnya dapat membantu meningkatkan efesiensi dengan mengurangi kemungkinan penggelembungan asset (Eberhard, Lavin, Montecinos-Pearce, \& Arenas, 2019). Hasil penelitian (Yuan, Wu, \& Xu, 2011) di Cina menunjukkan bahwa analis sekuritas Cina dapat menggunakan sarana pengumpulan informasi 
dan kemampuan analisis pakar untuk mengumumkan informasi perkiraan laba yang berharga, yang akan mendorong lebih banyak informasi spesifik perusahaan ke dalam harga saham.

Dalam melakukan seleksi pemilihan beragam dan unik. Berdasarkan hasil analisis kami terhadap beberapa jurnal dan artikel ilmiah yang telah kami review, terdapat banyak karakteristik perilaku yang dilakukan analis efek. Namun pada artikel ini kami akan lebih fokus membahas perilaku herding di antara para analis efek. Perilaku herding merupakan perilaku investor yang cenderung mengikuti investor lain dalam berinvestasi tanpa melakukan analisis fundamental terlebih dahulu sehingga pasar yang terbentuk menjadi tidak efisien (Fityani \& Arfinto, 2015). Analis keseluruhan cenderung bergerak ke arah konsensus ketika mengeluarkan rekomendasi, dan kecenderungan ini meningkat dengan sentimen pasar. Selain itu, efek dari sentimen pasar pada perkumpulan analis terutama terjadi untuk rekomendasi pada perusahaan yang sulit dinilai, perusahaan besar, serta perusahaan dengan kepemilikan institusional yang tinggi, rasio book-to-market yang tinggi dan cakupan yang rendah oleh analis (M. T. Chiang \& Lin, 2019). Semakin banyak perkiraan masalah analis, semakin tinggi kemungkinan analis mengambil keputusan yang lebih heuristik dengan melakukan herding lebih dekat dengan ramalan consensus (Hirshleifer, Levi, Lourie, \& Teoh, 2019). Temuan kami menunjukkan bahwa setiap industri memiliki, pada tingkat tertentu, perilaku herding di antara analis (Zhao, Zhang, Feng, \& Zhang, 2014).

Berdasarkan analisis kami, perilaku herding terjadi hampir di seluruh belahan dunia. Mulai dari Benua Asia, perilaku herding terjadi di Vietnam (Vo \& Phan, 2016, 2019), Pakistan (Shah, Shah, \& Khan, 2017), India (Bhaduri \& Mahapatra, 2013; Ganesh, Gopal, \& Thiyagarajan, 2018), Cina (T. C. Chiang, Li, \& Tan, 2010; Gong \& Dai, 2017; Lan, 2014; Lao \& Singh, 2011; Li, Liu, \& Park, 2017;
Yao, Ma, \& He, 2014; Zheng, Li, \& Chiang, 2017), Jepang (Cajueiro \& Tabak, 2009; Zheng et al., 2017), Korea (Zheng et al., 2017), Hongkong (Zheng et al., 2017), Taiwan (W. T. Lin, Tsai, \& Lung, 2013; Zheng et al., 2017), Turki (Akçaalan, Dindaroğlu, \& Binatlı, 2018), Kuwait (Balcilar, Demirer, \& Hammoudeh, 2013), Qatar (Balcilar et al., 2013; Medhioub \& Chaffai, 2018), dan Arab Saudi (Balcilar et al., 2013; Medhioub \& Chaffai, 2018). Lalu, di Benua Amerika perilaku herding juga terbukti terjadi di US (Bernales, Verousis, \& Voukelatos, 2016; Lee, 2017) dan Chile (Lavin \& Magner, 2014). Lalu, di Benua Afrika perilaku herding juga terbukti terjadi di Trinidad \& Tobago (Arjoon \& Bhatnagar, 2017) dan beberapa negara di perbatasan Afrika yaitu Botswana, Ghana, Kenya, Namibia, Nigeria, Tanzania dan Zambia (Guney, Kallinterakis, \& Komba, 2017). Lalu, Di Benua Eropa perilaku herding juga terjadi di Perancis (Khan, Hassairi, \& VIVIANI, 2011; Litimi, 2017), Jerman (Khan et al., 2011), Italia (Khan et al., 2011), Inggris (Khan et al., 2011), Finlandia (Lindhe, 2012), Romania (Pop, 2013), Portugal (Leite, Machado-Santos, \& Silva, 2018), Yunani (Messis \& Zapranis, 2014), dan Rusia (Indārs, Savin, \& Lublóy, 2019). Terakhir, perilaku herding juga terjadi di Benua Australia (AlShboul, 2012).

Faktor-faktor yang menyebabkan terjadinya perilaku herding sangat beragam. Analis lebih cenderung untuk melakukan herding ketika saham memiliki sentimen berita negatif, Perilaku herding analis didorong oleh insentif dan kekhawatiran karir yang dimiliki analis. Ini menunjukkan bahwa, dari sudut pandang analis, herding adalah rasional, karena mereka memaksimalkan utilitas mereka sendiri.

Dari perspektif pasar, ini menyiratkan bahwa rekomendasi analis akan mengandung bias yang mencerminkan insentif ini dan masalah karir dan sulit untuk diselesaikan kecuali insentif dapat diubah (Frijns \& Huynh, 2018). Hasil penelitian menunjukkan bahwa, selain risiko pasar dan ketidakpastian tingkat perusahaan, kecenderungan analis untuk 
herding meningkat dengan ketidakpastian agregat (M. C. Lin, 2018). Secara khusus, herding tampaknya didorong terutama oleh ketidakpastian pasar, kondisi pasar yang ekstrem dan periode arus informasi yang tinggi (Arjoon \& Bhatnagar, 2017; Bernales et al., 2016; Bhaduri \& Mahapatra, 2013; Bouri, Gupta, \& Roubaud, 2019; Cajueiro \& Tabak, 2009; Dong, Gu, \& Han, 2010; Indārs et al., 2019; Lan, 2014; Lao \& Singh, 2011; Lindhe, 2012; Vo \& Phan, 2016). Investor cenderung melakukan herding lebih dekat ketika mereka menghadapi risiko volatilitas tinggi (AlShboul, 2012; Balcilar et al., 2013; Bernales et al., 2016; Humayun Kabir \& Shakur, 2018; Vo \& Phan, 2016). Herding menjadi semakin kuat saat kita bergerak ke arah saham yang lebih kecil (Arjoon \& Bhatnagar, 2017; Guney et al., 2017; M. C. Lin, 2018; Yao et al., 2014). Kami juga menemukan bukti kuat herding selama periode pergerakan harga menengah ke besar (Lee, 2017). Investor lebih cenderung melakukan herding selama periode krisis (Li et al., 2017; Litimi, 2017; Ouarda, Bouri, \& Bernard, 2013; Shah et al., 2017). Kami juga menemukan bahwa herding pada industri lebih terasa di pasar yang menurun (Medhioub \& Chaffai, 2018; Yao et al., 2014; Zheng et al., 2017). Hasil empiris menunjukkan bahwa kenaikan suku bunga dan depresiasi mata uang Cina (CNY) akan menyebabkan herding (Gong \& Dai, 2017). Bukti empiris menunjukkan bahwa herding pada reksa dana terkait dengan lingkungan informasi yang buruk dan kualitas pengungkapan yang rendah (Deng, Hung, \& Qiao, 2018).

Dari beberapa hasil penelitian yang telah kami analisis juga terdapat beberapa hasil penelitian di sejumlah negara yang menunjukkan tidak adanya perilaku herding di pasar saham mereka. Perilaku herding tidak ditemukan di negara Pakistan (Javaira \& Hassan, 2015; Javed, Zafar, \& Hafeez, 2001), Cina (Lan, 2014), Denmark (Lindhe, 2012), Norwegia (Lindhe, 2012), Swedia (Lindhe, 2012)), Spanyol (Ahmed, 2019) dan Indonesia (Ramadhan \& Mahfud, 2016;
Saputra \& Sitinjak, 2018).

Studi pada investor pasar Spanyol menyimpulkan bahwa, baik sebelum atau setelah krisis, cenderung tidak meninggalkan informasi pribadi mereka dan membentuk herding sehingga membuat keputusan investasi yang rasional (Ahmed, 2019). Investor pada pasar saham Indonesia memiliki perilaku yang rasional dalam mengambil keputusan investasinya, dikarenakan informasi yang dibutuhkan oleh investor yang berkaitan dengan pergerakan harga saham di pasar dapat diakses dengan baik sehingga investor menjadikannya sebagai dasar analisis investasi. Tidak terdeteksinya herding pada pasar saham Indonesia disebabkan karena tidak terjadi kondisi market stress sepanjang tahun 20112015. Pada saat market stress, investor cenderung untuk menekan pemikiran mereka dan lebih mengikuti konsensus pasar, sehingga perilaku herding cenderungakan terjadi pada periode ini (Ramadhan \& Mahfud, 2016). Hasil penelitian (Kumari, Chandra, \& Pattanayak, 2019) mengungkapkan bahwa mengharapkan kepribadian yang patuh tidak ada yang menunjukkan kecenderungan terhadap perilaku herding. Investor yang memiliki kepribadian yang patuh lebih dipengaruhi oleh faktor pendorong social. Namun, faktor kognitif memotivasi kepribadian agresif, serta menghambat perilaku herding (Kumari et al., 2019).

Berdasarkan analisis kami juga ditemukan bahwa ada hasil penelitian yang berlawanan hasilnya di negara-negara seperti Pakistan dan Cina. Penelitian di Bursa Efek Pakistan pada tahun 2004-2013 yang membuktikan adanya perilaku herding pada investor lebih cenderung mengikuti pasar selama periode krisis (Shah et al., 2017). Sedangkan berdasarkan hasil data stok harian dan bulanan dari Bursa Efek Karachi menunjukkan tidak adanya perilaku herding untuk periode 2002-2007 dan tidak menemukan dukungan untuk model penetapan harga aset rasional dan perilaku investor yang ditemukan tidak efisien. Studi ini membantah bukti herding yang terbukti karena asimetri 
pengembalian pasar, status volume perdagangan tinggi dan rendah dan volatilitas pasar asimetris. Fundamental makro ekonomi memiliki peran yang tidak signifikan dalam proses pengambilan keputusan investor sehingga tidak berdampak pada perilaku herding (Javaira \& Hassan, 2015). Kedua penelitian tersebut sama-sama menggunakan pendekatan Christie dan Huang (1995). Kami sendiri menyimpulkan bahwa perbedaan hasil tersebut diakibatkan karena adanya perbedaan periode sampel penelitian. Pada penelitian (Shah et al., 2017), herding ditemukan di perusahaan besar dan cenderung tidak ditemukan pada perusahaan kecil. Lalu di Cina sendiri, beberapa hasil penelitian yang membuktikan adanya herding di pasar saham Cina menyimpulkan bahwa perilaku herding disebabkan oleh terjadinya krisis dan kondisi pasar yang bergejolak (Li et al., 2017; Zheng et al., 2017). Namun pada penelitian yang menunjukkan tidak adanya perilaku herding menunjukkan bahwa tidak terjadi herding selama dan setelah periode krisis, fenomena herding tidak terlihat jelas di pasar perumahan Cina. Herding lebih mungkin terjadi pada periode sebelum krisis keuangan (Lan, 2014). Perbedaaan hasil tersebut hanya terjadi di segmen saham perusahaan perumahan, dimana tidak ditemukan adanya herding pada pasar saham perusahaan perumahan di Cina.

Dari beberapa faktor penyebab terjadinya herding, kami menyoroti krisis ekonomi atau krisis keuangan sebagai salah satu faktor penyebab terjadinya perilaku herding di pasar saham. Karena berdasarkan hasil penelitian terdapat pro dan kontra dimana ada pasar saham yang terindikasi herding pada saat terjadi krisis dan ada pasar saham yang tidak terindikasi herding saat terjadi krisis. Di Pakistan ditemukan bahwa investor lebih cenderung mengikuti pasar selama periode krisis (Shah et al., 2017). Herding juga hadir di pasar saham Perancis selama periode krisis yang terjadi dari 2000 hingga 2016 (Litimi, 2017). Di Cina juga ditemukan bukti terjadi herding selama periode turbulen, terutama selama krisis keuangan (Li et al., 2017). Sedangkan di Turki, Investor tidak melakukan herding selama krisis ekonomi, tetapi mengikuti peristiwa penting yang meningkatkan ketegangan politik di negara ini (Akçaalan et al., 2018). Lalu di Romania, herding berlawanan dengan kepercayaan umum, dimana krisis telah berkontribusi pada pengurangan herding dan jelas diidentifikasi sebagai titik balik dalam perilaku herding (Pop, 2013). Studi lain juga menyimpulkan bahwa investor di pasar saham Spanyol, baik sebelum atau setelah krisis, cenderung tidak meninggalkan informasi pribadi mereka dan tidak melakukan herding sehingga membuat keputusan investasi yang rasional (Ahmed, 2019).

Selain perilaku herding, kami juga menemukan beberapa perilaku analis efek dalam proses pemilihan saham yaitu sebagai berikut. Pertama, yaitu perilaku analis efek yang bekerja di bank investasi. Analis yang bekerja di bank investasi yang lebih terkemuka yang mengeluarkan laporan yang lebih optimis, atau laporan yang lebih berani, atau laporan yang mendukung, atau berita yang mendukung, cenderung memiliki karir yang lebih pendek daripada analis lain yang tidak mengeluarkan laporan ini. Temuan ini mendukung pandangan bahwa bank investasi, sebagai pemberi kerja analis, menempatkan reputasi mereka di pasar modal untuk mengikat keandalan laporan analis mereka, menyediakan mekanisme untuk menyelesaikan bahaya moral analis (Altınkılıç, Balashov, \& Hansen, 2019).

Kedua, yaitu perilaku analis yang dimotivasi oleh adanya insentif hubungan kerja. Studi (Akono, Karim, \& Nwaeze, 2019) di AS menemukan bukti yang menunjukkan bahwa analis dengan pengalaman tinggi lebih rentan terhadap insentif hubungan kerja dan ini bisa menjadi penjelasan mengapa mereka lebih banyak bergaul, meskipun mereka seharusnya lebih terampil dalam peramalan.

Ketiga, yaitu perilaku analis yang memiliki saham di perusahaan yang sedang dianalisis. Analis yang memiliki saham di perusahaan yang mereka ikuti membuat 
rekomendasi yang lebih informatif dan melakukan lebih banyak upaya dalam meliput perusahaan. Temuan ini menunjukkan bahwa kepemilikan saham analis meningkatkan kredibilitas rekomendasi mereka dengan menyampaikan informasi superior mereka, tetapi juga mendorong analis untuk bias ke atas perkiraan harga target mereka (Chan, Lin, Yu, \& Zhao, 2018).

Keempat, yaitu perilaku konsensus pada perkumpulan analis. Hasil menunjukkan bahwa analis keseluruhan cenderung bergerak ke arah konsensus ketika mengeluarkan rekomendasi, dan kecenderungan ini meningkat dengan sentimen pasar (M. T. Chiang \& Lin, 2019). Meskipun analis benar- benar menerjemahkan valuasi perkiraan pendapatan mereka menjadi rekomendasi, efektivitas proses ini dikurangi oleh sentimen investor hanya pada saham yang memiliki sentimen sangat sensitif (Corredor, Ferrer, \& Santamaria, 2019).

Kelima, yaitu perilaku analis yang kurang akurat dalam menilai BUMN. Koneksi politik mendorong analis untuk lebih optimis pada BUMN dan bahkan menghasilkan rekomendasi "Beli" dan "Tahan" yang menyesatkan. Hasil penelitian ( $\mathrm{He} \& \mathrm{Ma}$, 2019) menunjukkan adanya bias optimisme di kalangan analis yang terhubung secara politik pada perusahaan milik negara di Cina. Analis Cina secara umum terlalu optimis dan bahwa pengaruh koneksi politik adalah salah satu alasan yang mungkin untuk ketidakakuratan analis di China (He \& Ma, 2019).

Keenam, yaitu perilaku analis yang mengalami kelelahan dalam proses analisis saham. Penelitian (Hirshleifer et al., 2019) menemukan bahwa semakin banyak perkiraan masalah analis, semakin tinggi kemungkinan analis mengambil keputusan yang lebih heuristik dengan melakukan herding lebih dekat kepada ramalan konsensus.

Ketujuh, yaitu perilaku analis yang berposisi sentral dalam suatu perkumpulan analis. Analis dengan posisi yang lebih sentral dalam jaringan akan mendapatkan kinerja perkiraan pendapatan yang lebih baik dengan volatilitas perkiraan yang lebih rendah dan akurasi perkiraan yang lebih tinggi. Analis dengan sentralitas jaringan yang lebih besar akan mendapatkan kinerja perkiraan pendapatan yang lebih baik (Hou, Zhao, \& Yang, 2018).

Kedelapan, yaitu perilaku analis yang memiliki nama keluarga/marga di mata investor. Hasil penelitian (J. H. Jung, Kumar, Lim, \& Yoo, 2019) menggunakan catatan imigrasi historis AS dan Gallup data survei, menemukan bukti kuat bahwa analis dengan nama keluarga yang lebih menguntungkan menimbulkan reaksi pasar yang lebih kuat terhadap revisi perkiraan mereka. Hasilnya konsisten dengan bias para investor dalam penilaian mereka dalam upaya untuk mencari konsistensi antara persepsi mereka tentang nama keluarga analis dan evaluasi mereka terhadap perkiraan kualitas analis.

Kesembilan, yaitu perilaku analis yang berafiliasi. Analis yang berafiliasi yaitu, analis dengan ikatan bisnis yang lebih dekat dengan perusahaan yang mereka ikuti (M. C. Lin, 2018). Penelitian (Liao \& Chang, 2014) di Taiwan telah menunjukkan bahwa afiliasi perbankan investasi menghasilkan tekanan pada analis untuk menghasilkan rekomendasi optimis mengenai saham afiliasi. Hasil penelitian (Huyghebaert \& Xu, 2016) di Cina menemukan bahwa analis yang berafiliasi menghasilkan perkiraan yang lebih positif, dan akurasi perkiraan mereka juga jauh lebih rendah. Akurasi relatif analis terafiliasi juga lebih buruk dalam jangka waktu ini. Perkiraan pendapatan jangka panjang analis yang berafiliasi dengan perusahaan tunduk pada optimisme berlebih dibandingkan dengan perkiraan analis yang tidak berafiliasi. Selain itu, perkiraan jangka pendek oleh analis terafiliasi cenderung lebih konservatif dibandingkan dengan rekan-rekan non-afiliasi mereka yang mungkin menunjukkan manajemen perkiraan pendapatan yang lebih rendah untuk menghindari kejutan pendapatan negatif (Prokop \& Kammann, 2018). Penelitian (Lim \& Kim, 2019) pada analis berafiliasi chaebol di Korea menemukan bahwa investor mampu mengidentifikasi bias optimis dalam rekomendasi 'buy' analis yang berafiliasi 
dengan chaebol dan secara efektif mendiskonnya di sekitar tanggal pengumuman awal dengan menguji reaksi pasar jangka pendek dan volume perdagangan abnormal.

Kesepuluh, yaitu perilaku analis yang menghasilkan bias keputusan. Analis rentan terhadap bias perilaku serta potensi konflik kepentingan dalam keputusan rekomendasi pembelian saham baru mereka (MokoaleliMokoteli, Taffler, \& Agarwal, 2009). Manajemen perusahaan tertutup yang ditanamkan secara signifikan meningkatkan bias analis. Bias analis meningkat dengan meningkatnya entrenchment manajerial (Ulupinar, 2018). Penelitian (Corwin, Larocque, \& Stegemoller, 2017) menemukan pengurangan substansial dalam bias afiliasi analis setelah penyelesaian untuk bank yang terkena sanksi. Sebaliknya, kami menemukan bukti kuat bias sebelum dan sesudah penyelesaian untuk analis yang berafiliasi di bank yang tidak terkena sanksi. Hasil kami menunjukkan bahwa penyelesaian

menyebabkan peningkatan dalam biaya yang diharapkan untuk mengeluarkan cakupan bias di bank-bank yang terkena sanksi, sementara perubahan peraturan organisasi pengaturan diri secara bersamaan sebagian besar tidak efektif dalam mengurangi pengaruh perbankan investasi pada penelitian analis di bank-bank besar yang tidak terkena sanksi.

Dalam menjalani profesi sebagai analis efek, para analis seringkali dihadapkan dengan adanya persaingan dengan analis lain serta adanya perdagangan informasi yang membuat reputasi mereka dipertaruhkan. Beberapa analisis analis mungkin hanya dimotivasi oleh masalah status. Kadang persaingan di pasar tidak terkait dengan pasar itu sendiri dan sebaliknya disebabkan oleh kompetisi yang didorong oleh persaingan antar "aktor" yang terkait demi posisi sosial dan didorong oleh penciptaan pasar yang unggul (Bowers, Greve, \& Mitsuhashi, 2017). Penelitian (Frijns \& Huynh, 2018) menemukan tiga hasil utama. Pertama, menemukan bahwa jumlah analis berkurang ketika saham diliput lebih banyak di media. Kedua, ketika perusahaan memiliki sentimen media negatif, analis cenderung lebih banyak melakukan herding. Ketiga, ketidaksepakatan yang lebih tinggi di media dikaitkan dengan kecenderungan yang lebih tinggi untuk herding di antara para analis. Pedagang dapat memperoleh keuntungan besar jika mereka memiliki akses ke informasi dalam laporan ini sebelum rilis publik mereka. Analis memiliki insentif untuk memberi tip klien utama mereka dengan mendapatkan komisi pada perdagangan informasi (Mao, Segara, \& Westerholm, 2019). Penelitian (M. J. Jung, Keeley, \& Ronen, 2019) menunjukan bahwa estimasi analis terlalu optimis, estimasi analis awal cenderung berjalan oleh manajemen dan revisi terhadap estimasi sangat berhubungan dengan pengembalian saham kontemporer. Revisi analis yang diprediksi dapat menambah sinyal pasar saham lainnya yang digunakan oleh pelaku pasar untuk memprediksi pengembalian saham.

\section{KESIMPULAN DAN SARAN}

Berdasarkan hasil analisis, kami menyimpulkan bahwa perilaku herding adalah perilaku ikut-ikutan yang dilakukan oleh analis/investor saham dalam pengambilan keputusan pemilihan saham tanpa melakukan analisis fundamental terlebih dahulu sehingga pasar yang terbentuk menjadi tidak efisien. Herding terjadi hampir di seluruh pasar saham di berbagai belahan dunia. Faktor-faktor yang menyebabkan terjadinya perilaku herding antara lain adalah adanya sentimen berita negatif terhadap saham yang dianalisis, adanya insentif dan kekhawatiran karir yang dimiliki analis, risiko pasar dan ketidakpastian tingkat perusahaan, ketidakpastian agregat, ketidakpastian pasar, kondisi pasar yang ekstrem, periode arus informasi yang tinggi, risiko volatilitas tinggi, analisis jenis saham yang lebih kecil, terjadinya krisis ekonomi/keuangan, keadaan pasar yang menurun, kenaikan suku bunga, depresiasi mata uang, lingkungan informasi yang buruk dan kualitas pengungkapan yang rendah. Herding dilakukan dengan tujuan menghindari risiko kesalahan pengambilan keputusan dalam 
pemilihan saham yang sulit dinilai karena keputusan yang diambil lewat herding mengikuti keputusan yang berkembang diantara sejumlah analis atau investor lain.

Keterbatasan dalam artikel ini adalah kurang meratanya data yang diambil dari hasil riset di beberapa pasar saham seperti kurangnya pengambilan data dari pasar saham yang ada di benua Amerika.

\section{DAFTAR PUSTAKA}

Adhikara, M. F. A. (2011). Perilaku Mental Discounting Analis Efek Di Bursa Efek Indonesia (BEI). Jurnal dan Prosiding SNA - Simposium Nasional Akuntansi, 14(1), 21-22.

Ahmed, M. (2019). Herd Behaviour in Extreme Conditions : an evidence from Spanish Market Herd Behaviour in Extreme Conditions : an evidence from Spanish Market Herding, when considered in financial decision making, is phenomenon where an economic agent tends to imitate $t$. (February 2016).

Ajzen, I. (1991). The Theory of Planned Behavior. Organizational Behaviour Human Decision Process, 50(2), 179211.

Akçaalan, E., Dindaroğlu, B., \& Binatlı, A. O. (2018). Herd Behavior in Borsa Istanbul, 2001-2016. (August),1-26. https://doi.org/10.13140/RG.2.2.2090 $8.77445 / 1$

Akono, H., Karim, K., \& Nwaeze, E. (2019). Analyst Rounding of EPS Forecasts and Stock Recommendations. dvances in Accounting,44 (July 2017), 6880.https://doi.org/10.1016/j.adiac.2018 .10 .002

Al-Shboul, M. Q. (2012). Asymmetric Effects and the Herd Behavior in the Australian Equity Market. International Journal of Business and Management, $7(7)$. https://doi.org/10.5539/ijbm.v7n7p121 Altınkılıç, O., Balashov, V. S., \& Hansen, R. S. (2019). Investment Bank
Monitoring and Bonding of Security Analysts' Research. Journal of Accounting and Economics, 67(1), 98119. https://doi.org/10.1016/j.jacceco.2018.0 8016

AndreaDevenow, \& Ivo Welch. (1996). Rational Herding in Financial Economics. European Economic Review, 403(3-5), 603-615.

Arjoon, V., \& Bhatnagar, C. S. (2017). Dynamic Herding Analysis in a Frontier Market. Research in International Business and Finance, 42, 496-508. https://doi.org/10.1016/j.ribaf.2017.01.0 06

Balcilar, M., Demirer, R., \& Hammoudeh, S. (2013). Investor Herds and Regimeswitching: Evidence from Gulf Arab stock markets. Journal of International Financial Markets, Institutions and Money, 23(1), 295-321. https://doi.org/10.1016/j.intfin.2012.09. 007

Barber, B. M., \& Odean, T. (2000). Trading Is Hazardous to Your Wealth: The Common Stock Investment Performance of Individual Investors. Journal of Finance, 55(2), 773-806.

https://doi.org/10.1111/00221082.00226

Bernales, A., Verousis, T., \& Voukelatos, N. (2016). Do Investors Follow The Herd in Option Markets? Journal of Banking and

Finance. https://doi.org/10.1016/j.jbankfin.2016.0 2.002

Bhaduri, S. N., \& Mahapatra, S. D. (2013). Applying An Alternative Test of Herding Behavior: A Case Study of The Indian Stock Market.Journal of Asian Economics, 25,43-52. https://doi.org/10.1016/j.asieco.2013.02. 001

Bikhchandani, S., Hirshleifer, D., \& Welch, I. (1992). A Theory of Fads, Fashion, Custom, and Cultural Change as Informational Cascades. Journal of 
Political Economy, 100(5), 992-1026. https://doi.org/10.1086/261849

Bikhchandani, S., \& Sharma, S. (2000). Behaviour in Financial Markets; A Review.

Bouri, E., Gupta, R., \& Roubaud, D. (2019). Herding Behaviour in Cryptocurrencies. Finance Research Letters, 29, 216221.https://doi.org/10.1016/j.frl.2018.0 7.008 Bowers, A. H., Greve, H. R., \& Mitsuhashi,

H. (2017). Look At Me: Overt Status- Seeking Behavior And Competitive Emergence Among Securities Analysts. Sociology of Organizations, 50, 351- 382.

Cajueiro, D. O., \& Tabak, B. M. (2009). Multifractality and Herding Behavior in The Japanese Stock Market. Chaos, Solitons and Fractals, 40(1), 497-504. https://doi.org/10.1016/j.chaos.2007.0 7.091

Chan, J., Lin, S., Yu, Y., \& Zhao, W. (2018). Analysts' Stock Ownership and Stock Recommendations. Journal of Accounting and Economics, 66(2-3), 476-498.

https://doi.org/10.1016/j.jacceco.2018. 08.010

Chiang, M. T., \& Lin, M. C. (2019). Market Sentiment and Herding in Analysts' Stock Recommendations. North American Journal of Economics and Finance, $\quad 48, \quad 48-$ 64. https://doi.org/10.1016/j.najef.2019.01. 007

Chiang, T. C., Li, J., \& Tan, L. (2010). Empirical Investigation of Herding Behavior in Chinese Stock Markets: Evidence from Quantile Regression Analysis. Global Finance Journal, 21(1), 111-124.https://doi.org/10.1016 /j.gfj.2010.03.005

Corredor, P., Ferrer, E., \& Santamaria, R. (2019). The Role of Sentiment And Stock Characteristics in The Translation of Analysts' Forecasts into
Recommendations. North American Journal of Economics and Finance, 49, 252-272.https://doi.org/10.1016 /j.najef.2019.04.008

Corwin, S. A., Larocque, S. A., \& Stegemoller, M. A. (2017). Investment Banking Relationships and Analyst Affiliation Bias: The Impact of The Global Settlement on Sanctioned and NonSanctioned Banks. Journal of Financial Economics, 124(3), 614-631. https://doi.org/10.1016/j.jfineco.2017.0 3. 005

Deng, X., Hung, S., \& Qiao, Z. (2018). Mutual Fund Herding and Stock Price Crashes. Journal of Banking and Finance, 94, 166-184. https://doi.org/10.1016/j.jbankfin.2018.0 7.014

Dong, Z., Gu, Q., \& Han, X. (2010). Ambiguity Aversion and Rational Herd Behaviour. Applied Financial Economics,20(4), 331-343.

https://doi.org/10.1080/09603100903299 675

Eberhard, J., Lavin, J. F., Montecinos-Pearce, A., \& Arenas, J. (2019). Analyzing Stock Brokers' Trading Patterns: A Network Decomposition and Spatial Econometrics Approach. Complexity, 118.

Elena, R. (2013). Munich Personal Repec Archive Herd Behavior Towards The Market Index : Evidence From Romanian Stock Exchange Herd Behavior Towards The Market Index : (51595).

Fityani, I., \& Arfinto, E. D. (2015). Analisis Investor Herding Behavior dengan Multinomial Logit Regression pada BEI (Studi Kasus pada Saham LQ-45 Periode 2009-2014). Diponegoro Journal of Management, 4(3), 1-14.

Foucault, T., Sraer, D., \& Thesmar, D. J. (2011). Individual Investors and Volatility. Journal of Finance, 66(4), 1369-1406. $\quad$ https://doi.org/10.1111/ j.1540-6261.2011.01668.x 
Frijns, B., \& Huynh, T. D. (2018). Herding in Analysts' Recommendations: The role of media. Journal of Banking and Finance, $\quad 91$, 1-18. https://doi.org/10.1016/j.jbankfin.2018. 03.010

Ganesh, R., Gopal, N., \& Thiyagarajan, S. (2018). Bulk and Block Holders Herding Behaviour. South Asian Journal of Business Studies, 7(2), 150171. https://doi.org/10.1108/SAJBS-122017- 0139

Gong, P., \& Dai, J. (2017). Monetary Policy, Exchange Rate Fluctuation, and Herding Behavior in The Stock Market. Journal of Business Research, 76 , 34-43. https://doi.org/10.1016/j.jbusres.2017. 02. 018

Guney, Y., Kallinterakis, V., \& Komba, G. (2017). Herding in Frontier Markets: Evidence from African Stock Exchanges. Journal of International Financial Markets, Institutions and Money, 47, 152-175. https://doi.org/10.1016/j.intfin.2016.1 1.001

He, F., \& Ma, Y. (2019). Do Political Connections Decrease The Accuracy of Stock Analysts' Recommendations in The Chinese Stock Market? Economic Modelling, 81,59-72. https://doi.org/10.1016/j.econmod.201 8. 12.012

Hirshleifer, D., Levi, Y., Lourie, B., \& Teoh, S. H. (2019). Decision Fatigue and Heuristic Analyst Forecasts. Journal of Financial Economics, 133(1), 83-98. https://doi.org/10.1016/j.jfineco.2019. 01.005

Hou, J., Zhao, S., \& Yang, H. (2018). Security Analysts' Earnings Forecasting Performance Based on Information Transmission Network. Physica A: Statistical Mechanics and Its Applications, 509(37), 611-619. https://doi.org/10.1016/j.physa.2018.0 6.093
Humayun Kabir, M., \& Shakur, S. (2018). Regime-Dependent Herding Behavior in Asian and Latin American Stock Markets. Pacific Basin Finance Journal, $\quad 47, \quad 60-78$. https://doi.org/10.1016/ j.pacfin.2017.12.002

Huyghebaert, N., \& Xu, W. (2016). Bias In The Post-IPO Earnings Forecasts of Affiliated Analysts: Evidence From A Chinese Natural Experiment. Journal of Accounting and Economics, 61(2-3), 486-505. https://doi.org/10.1016 /j.jacceco.2015.10.002

Indārs, E. R., Savin, A., \& Lublóy, Á. (2019). Herding Behaviour in an Emerging Market: Evidence from The Moscow Exchange. Emerging Markets Review, 38, 468-487. https://doi.org/10.1016 /j.ememar.2018.12.002

Javaira, Z., \& Hassan, A. (2015). An Examination of Herding Behavior in Pakistani Stock Market. International Journal of Emerging Markets, 10(3), 474-490.

Javed, T., Zafar, N., \& Hafeez, B. lal. (2001). Herding Behavior in Karachi Stock Exchange. International Journal of Management Sciences and Business Research, 2(2), 19-28.

Jiani, W., \& Liu, M. (2014). The Accuracy And Effectiveness of Securities Analysts' Pricing Forecast-Empirical Research Based on A-Share Ipos. Procedia Computer Science, 31(Itqm), 587596.https://doi.org/10.1016/j.procs.2014. 05.305

Jung, J. H., Kumar, A., Lim, S. S., \& Yoo, C. Y. (2019). An Analyst by Any Other Surname: Surname Favorability and Market Reaction To Analyst Forecasts. Journal of Accounting and Economics. https://doi.org/10.1016/j.jacceco.2019.0 2.002

Jung, M. J., Keeley, J. H., \& Ronen, J. (2019). The Predictability of Analyst Forecast Revisions. Journal of Accounting, Auditing and Finance, 34(3), 434-457. 
Kallinterakis, V., Munir, N., \& RadovicMarkovic, M. (2010). Herd Behaviour, Illiquidity and Extreme Market States: Evidence from Banja Luka. Journal of Emerging Market Finance, 9(3), 305324.

Khan, H., Hassairi, S. A., \& VIVIANI, J.-L. (2011). Herd Behavior and Market Stress: The Case of Four European Countries. International Business Research, 4(3), 53-67. https://doi.org/10.5539/ibr.v4n3p53

Kim, M. J., \& Park, B.-J. (2017). A Dynamic Measure of Intentional Herd Behavior in Financial Markets A Dynamic Measure of Intentional Herd Behavior in Financial Markets *. Munich Personal RePEc Archive, (82025).

Kodres, L. E., \& Pritsker, M. (2002). A Rational Expectations Model of Financial Contagion. The Journal of Finance, LVII(2), 769-798.

Kumar, S., \& Goyal, N. (2015). Behavioural Biases in Investment Decision Making - A Systematic Literature Review. Qualitative Research in Financial Markets, 7(1),88-108. https://doi.org/10.1108/QRFM-072014- 0022

Kumari, S., Chandra, B., \& Pattanayak, J. K. (2019). Personality Traits and Motivation of Individual Investors Towards Herding Behaviour in Indian Stock Market. Kybernetes. https://doi.org/10.1108/K-11-20180635

Lan, T. (2014). Herding Behavior in China Housing Market. International Journal of Economics and Finance, 6(2). https://doi.org/10.5539/ijef.v6n2p115

Lao, P., \& Singh, H. (2011). Herding Behaviour in the Chinese and Indian Stock Markets. Journal of Asian Economics, 22(6), 495-506.

https://doi.org/10.1016/j.asieco.2011.0 8. 001
Lavin, J. F., \& Magner, N. S. (2014). Herding in The Mutual Fund Industry: Evidence from Chile. Academia Revista Latinoamericana de Administración, 27(1), 10-29.

Lee, K. (2017). Herd Behavior of The Overall Market: Evidence Based on The Cross-

Sectional Comovement of Returns. North American Journal of Economics and Finance, 42, 266-284. https://doi.org/10.1016/j.najef.2017.07.0 06

Leite, G. M., Machado-Santos, C., \& Silva,

A. F. Da. (2018). Destabilizing Impacts of Herding Behaviour in Portuguese Capital Market. Revista de Métodos Cuantitativos Para La Economía y La Empresa, 25, 3-22.

Li, H., Liu, Y., \& Park, S. Y. (2017). TimeVarying Investor Herding in Chinese Stock Markets. International Review of Finance, 59-90. https://doi.org/10.1111/ir

Liao, M. H., \& Chang, C. Y. (2014). Analysts' Forecasts and Institutional Investors' Behavior. Proceedings - 2014 8th International Conference on Innovative Mobile and Internet Services in Ubiquitous Computing, IMIS 2014, 575579.https://doi.org/10.1109/IMIS.2014.8 4 Lim, Y., \& Kim, H. (2019). Market Reaction to Optimistic Bias in The Recommendations of Chaebol-Affiliated Analysts. Journal of Contemporary Accounting and Economics, 15, $224=242$.

Lin, M. C. (2018). The Impact of Aggregate Uncertainty on Herding in Analysts' Stock Recommendations. International Review of Financial Analysis, 57(February), 90-105. https://doi.org/10.1016/j.irfa.2018.02.00 6

Lin, W. T., Tsai, S. C., \& Lung, P. Y. (2013). Investors' Herd Behavior: Rational or Irrational? Asia-Pacific Journal of Financial Studies, 42(5), 755-776. https://doi.org/10.1111/ajfs.12030 
Lindhe, E. (2012). Herd Behavior in Stock Markets. (August), 1-52.

Litimi, H. (2017). Herd Behavior in The French Stock Market. Review of Accounting and Finance, 16(4), 497-515. https://doi.org/10.1108/RAF11- 2016-0188

Mao, R., Segara, R., \& Westerholm, J. 2019). Analyst Tipping: Evidence on Finnish stocks. International Review of Financial Analysis, (February). https://doi.org/10.1016/j.irfa.2019.05.0 01

Medhioub, I., \& Chaffai, M. (2018). Islamic Finance and Herding Behavior: An ApplicationtTo Gulf Islamic Stock Markets. Review of Behavioral Finance, 10(2), 192-206.

Messis, P., \& Zapranis, A. (2014). Herding Behaviour and Volatility in The Athens Stock Exchange. Journal of Risk Finance, 15(5), 572-590.

Mihaylov, G., Cheong, C. S., \& Zurbruegg, R. (2015). Can Security Analyst Forecasts Predict Gold Returns? International Review of Financial Analysis, 41, 237246.https://doi.org/10.1016/j.irfa.2015. 03.012

Mokoaleli-Mokoteli, T., Taffler, R. J., \& Agarwal, V. (2009). Behavioural Bias And Conflicts of Interest in Analyst Stock Recommendations. Journal of Business Finance \& Accounting, 36(34), 384-418.

Ouarda, M., Bouri, A. el, \& Bernard, O. (2013). Herding Behavior under Markets Condition: Empirical Evidence on the European Financial Markets. International Journal of Economics and Financial Issues, 3(1).

Park, B. (2011). Asymmetric Herding as a Source of Asymmetric Return Volatility. Journal of Banking and Finance, 35(10), 26572665.https://doi.org/10.1016/j.jbankfin .2011 .02 .025

Pop, R. E. (2013). Herd Behavior Towards
The Market Index: Evidence from Romanian Stock Exchange. Munich Personal RePEc Archive.

Prokop, J., \& Kammann, B. (2018). The Effect of The European Markets in Financial Instruments Directive on Affiliated Analysts' Earnings Forecast Optimism. Journal of Economics and Business, 95, 75-86.

https://doi.org/10.1016/j.jeconbus.2017. 06.004

Ramadhan, T., \& Mahfud, M. K. (2016). Deteksi Perilaku Herding pada Pasar Saham Indonesia \& Singapura. 5(1992), 1-9.

Saputra, A. R., \& Sitinjak, E. L. M. (2018). Pengaruh Faktor-Faktor Keuangan Dan Perilaku Herding Investor Terhadap Underpricing Pada Penawaran Perdana Saham Perusahaan Yang Terdaftar Di Bei. Jurnal Ekonomi, Manajemen, Akuntansi Dan Perpajakan, 1(1), 1-25.

Shah, M. U. D., Shah, A., \& Khan, S. U. (2017). Herding Behavior in The Pakistan Stock Exchange: Some New Insights. Research in International Business and Finance, 42(July), 865$873 . \quad$ https://doi.org/10.1016 /j.ribaf.2017.07.022

Soorani, F., \& Ahmadvand, M. (2019). Determinants of Consumers' Food Management Behavior: Applying and Extending The Theory of Planned Behavior. Waste Management, 98, 151159.

Ullah, S., \& Ather, M. (2014). Munich Personal RePEc Archive Analysis of Herd Behavior Using Quantile Regression: Evidence from Karachi Stock Exchange ( KSE ). (55322).

Ulupinar, B. (2018). The Effect of Managerial Entrenchment on Analyst Bias. Global Finance Journal, 37(2017), 25-38. https://doi.org/10.1016/j.gfj.2018.04.001

Vo, X. V., \& Phan, D. B. A. (2016). Herd Behavior in Emerging Equity Markets: Evidence from Vietnam. Asian Journal of Law and Economics, 7(3), 369-383. 
https://doi.org/10.1515/ajle-2016-0020

Vo, X. V., \& Phan, D. B. A. (2019). Herd Behavior and Idiosyncratic Volatility in A Frontier Market. Pacific Basin Finance Journal,53,321-330. https://doi.org/10.1016/j.pacfin.2018.10 .005

Wahlund, R., \& Gunnarsson, J. (1996). Mental Discounting and Financial Strategies. Journal of Economic Psychology, 17, 709-730.

Yao, J., Ma, C., \& He, W. P. (2014). Investor Herding Behaviour of Chinese Stock Market. International Review of Economics and Finance, 29, 12-29. https://doi.org/10.1016/j.iref.2013.03.0 02

Yuan, Z., Wu, L., \& Xu, B. (2011). Empirical Research About The Influence of Analysts Following Behavior on Stock Price Informativeness. 2011 International Conference on Management Science and Industrial Engineering, MSIE 2011, 33-37. https://doi.org/10.1109/MSIE.2011.57 07725

Zhao, Z., Zhang, Y., Feng, X., \& Zhang, W. (2014). An Analysis of Herding Behavior in Security Analysts' Networks. Physica A: Statistical Mechanics and Its Applications, 413, 116-124. https://doi.org/10.1016/j.physa.2014.06. 082

Zheng, D., Li, H., \& Chiang, T. C. (2017). Herding Within Industries: Evidence From Asian Stock Markets. International Review of Economics and Finance, 51, 487509.https://doi.org/10.1016 /j.iref.2017.07.005 